УдК 351.853

E. O. Apxunoba,

к. філос. н.., дочент, дочент кафедри теорії та практики управління,

КПІ імені Ігоря Сікорського

ORCID ID: 0000-0002-1640-1488

O. O. Клевиук,

студентка, кафедра теорії та практики управління,

факультет сочіологї і права, КПІ імені Ігоря Сікорського

ORCID ID: 0000-0002-8050-6188

DOI: $10.32702 / 2306-6814.2021 .13-14.51$

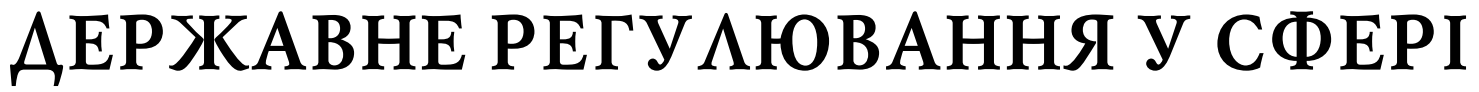 ОХОРОНИ КУ АЬТУРНОЇ СПААЩИНИ УКРАЇНИ
}

\author{
Ye. Arkhypova, \\ $\mathrm{PhD}$ in Philosophy, Associate Professor, Associate Professor of the Department \\ of Theory and Practice of Management, Igor Sikorsky Kyiv Polytechnic Institute \\ O. Klevchuk, \\ Student, Department of Theory and Practice of Management, \\ Sociology and Law Faculty, Igor Sikorsky Kyiv Polytechnic Institute
}

\section{STATE REGULATION IN THE FIELD OF PROTECTION OF CULTURAL HERITAGE OF UKRAINE}

\begin{abstract}
Метою статті є аналіз та надання рекомендацій щодо удосконалення державного регулювання у сфері охорони культурної спадщини України. Охарактеризовано сучасний стан усфері охорони культурної спадщини в Україні. На основі аналізу таких програм, орієнтованих на збереження та охорону культурної спадщини, визначено ряд типових для різних регіонів України проблем у цій сфері, зокрема: недостатність державного фінансування; розпорошеність правових норм, що стосуються сфери культурної спадщини, низька інформованість власників щодо їх обов'язків, недостатні санкції за порушення норм; відсутність або застарілість охоронної документації для великої частки об'єктів культурної спадщини; відсутність інформації про власників або балансоутримувачів частини пам'яток; несприятливий інвестиційний клімат. Визначено, що великим недоліком, який впливає на якість управління культурним спадком України, $\epsilon$ відсутність повноцінного обліку культурних пам'яток. Виділено фактори, які сприятимуть покращенню державного регулювання у сфері охорони культурних надбань.
\end{abstract}

Improving of state regulation in the field of protection of cultural heritage of Ukraine in economic, cultural, social, historical and patriotic and other contexts is an urgent task of the state. The purpose of the article is to analyze and provide recommendations for improving state regulation in the field of cultural heritage protection of Ukraine.

The current state in the field of cultural heritage protection in Ukraine is described. Based on the analysis of existing city and regional programs focused on the preservation and protection of cultural heritage, a number of typical problems for different regions of Ukraine in this area have been identified, in particular: lack of public funding; scattering of legal norms related to the sphere of cultural heritage under various legal acts, non-compliance with current legislation due to low awareness of owners and insufficient level of legal culture, insufficient sanctions for violations; lack or obsolescence of protective documentation for some cultural heritage sites; lack of information about the owners or balance holders; unfavorable investment climate to attract private foundations, sponsors or patrons, ets. 
It is determined that a major shortcoming that affects the quality of management of cultural heritage of Ukraine is the lack of full accounting of cultural monuments. The State Register of Cultural Heritage of Ukraine is being formed rather slowly and contains incomplete information, although the relevant ministry has rather ambitious plans for digitalization in the field of cultural heritage.

It is shown that the state needs to abandon the dispersion of management and control functions between several central executive bodies; establish a legal framework for the use of cultural heritage sites (protection, preservation, restoration, archeological excavations, documentation, etc.); stimulate public-private partnerships and patronage in the field of culture to actively involve the public, professional organizations and specialists in related fields in the dialogue, development and control over the implementation of state policy and local programs for the development and preservation of cultural heritage sites.

Ключові слова: культурна спадщина, збереження культурної спадщини, державне регулюВання, охорона культурної спадщини.

Key words: cultural heritage, preservation of cultural heritage, state regulation, protection of cultural heritage.

\section{ПОСТАНОВКА ПРОБАЕМИ}

Намагання України інтегруватися в європейський простір спонукає владні органи всіх рівнів та представників наукової спільноти до пошуку актуальних способів мобілізації всіх складових потенціалу держави та її регіонів, що потрібно для якісного розвитку економіки країни й підвищення рівня життя населення. Сьогодні здійснюється активне входження України до світового культурного простору, тому комплексне дослідження культурної спадщини України з метою її ефективного соціально-економічного використання, збереження та відновлення $€$ важливим науково-практичним та стратегічним завданням загальнодержавного значення. Згідно з Конституцією та законами України, низкою ратифрікованих чи підписаних Україною міжнародних конвенцій [1; 2], діяльність з охорони культурної спадщини є зобов' язанням нашої держави перед власними громадянами та світовим співтовариством.

Таким чином, удосконалення державного регулювання в сорері охорони культурної спадщини України в економічному, культурно-соціальному, історико-патріотичному та інших контекстах набуває надзвичайної актуальності.

\section{АНА ІІЗ ОСТ АНHIX АОС ІІАЖЕНЬ І ПУБ $І$ ІКАЦІЙ}

До питання охорони культурної спадщини в Україні та закордоном, а також до нормативно-правових чинників ії̈ забезпечення звертались такі українські та зарубіжні науковці: В. Акулєнко, М. Биков, Ю. Барабаш, Ю. Волошин, О. Гавриленко, В. Горбик, О. Єпіванов, С. Кот, Т. Курило, Т. Мазур, О. Малишева, Ю. Опалько, І. Пивовар, К. Поливач, В. Холодок, В. Шаповал тощо. Проблеми збереження та дослідження пам'яток аналізували також А. Бернат, Г. Боряк, Ж.-П. Валло, Г. Денисенко, О. Зараховський, Д. Лихачов, П. Нора, П. Скрипник, Ю. Опалько. Питання впливу об'єктів культурної спадщини на соціально-економічний розвиток вивчали такі дослідники: В.О. Ганський, А. Карвінська, І. Мартиненко, Я. Пурхля, Д. Ріпкем, А. Рубінштейн, Є. Хауснер та ін. Такі автори, як С. Бебко, А. Гаврилюк, В. Ганський,
О. Зараховський, С. Захарін, О. Рибчинський, Л. Черчик, І. Яковенко звертаються до дослідження державної політики, регіональних та місцевих програм, орієнтованих на збереження та розвиток різних об'єктів культурної спадщини.

\section{META CTATTI}

Метою статті $€$ аналіз та надання рекомендацій щодо удосконалення державного регулювання у сфрері охорони культурної спадщини України.

\section{ВИК ААА ОСНОВНОГО МАТЕРІААУ}

Основним завданням держави у галузі культурної спадщини є забезпечення умов для збереження культурної спадщини для майбутніх поколінь. Як слідує з [2], в України знаходиться близько 130 тисяч об'єктів культурної спадщини, які обліковувалися державою за нормами, що діяли до набрання чинності Законом України "Про охорону культурної спадщини", тобто до 2000 року. В державному реєстрі нерухомих пам'яток України (далі - Реєстр) [3] на середину травня 2021 року налічується більше 16 тисяч пам'яток національного та місцевого значення, серед яких найбільше археологічних пам'яток та пам'яток історії. Таким чином, близько 114 тисяч пам'яток, які взято на державний облік відповідно до законодавства, що діяло до 2000 року, наразі не включено до Реєстру.

Статус щойно виявленого об'єкта культурної спадщини має близько 34 тисяч пам'яток [2], тобто ці пам'ятки включені до Переліку об'єктів культурної спадщини, але не занесені до Реєстру [4], причому процедура занесення до Реєстру може тривати більше трьох років.

Державний реєстр нерухомих пам'яток України має бути розміщений в мережі Інтернет у вільному доступі та включати, окрім іншого, геопросторові дані та сервіси. Проте наразі він являє собою два архіви з текстовими фрайлами по областям України, м. Києву та Севастополю, причому ці фрайли містять дуже обмежену інформацію (назви пам'яток, їх вид, адреса, датування, охоронний номер, номер та дата рішення про взяття під охорону) [3]. Формування повноцінного електронного 
реєстру всіх об'єктів культурної спадщини є одним із головних завдань органів влади України.

Аналіз діючих міських та обласних програм, орієнтованих на збереження та охорону культурної спадщини [4-9], дозволяє визначити ряд типових для різних регіонів України проблем у цій сфері:

- недостатність державного фрінансування, що спричиняє занепад та знищення пам'яток культури;

- недостатня сорормованість та недотримання норм законодавства у сфері охорони та використання культурної спадщини;

— відсутність охоронної документації (взагалі або у сучасному форматі електронних паспортів) для великої частки об'єктів культурної спадщини, що готується, спираючись на відповідні науково-методичні засади, $\epsilon$ підставою їх реєстрації в Реєстрі та визначає основні засади їх фрункціонування, збереження та охорони, в тому числі забезпечує своєчасне проведення реставраційних робіт. Зокрема, згідно з [8], в Полтавській області наразі лише $30 \%$ усіх об'єктів культурної спадщини мають облікову документацію;

- відсутність інорормації про власників або балансоутримувачів частини пам'яток;

- недостатній рівень кваліфікації персоналу, в обов'язки якого входить формування окремих елементів електронних інформаційних ресурсів щодо пам'яток культури;

- несприятливий інвестиційний клімат для залучення приватних фондів, спонсорів чи благодійників для популяризації та відновлення культурної спадщини.

Великим недоліком, що впливає на якість управління культурним спадком України, є відсутність повноцінного обліку культурних пам'яток. Державний реєстр культурних надбань України формується досить повільно і містить неповну інформацію. Це перешкоджає презентації, розповсюдженню та популяризації культурної спадщини в Україні та за кордоном, а це б збільшувало туристичний потенціал держави [9; 10].

Процедура внесення об'єкта культурної спадщини до Реєстру передбачає складання науковими установами облікової документації на щойно виявлений об'єкт культурної спадщини. Уповноважений орган має забезпечити складання цієї документації у строк до трьох років після внесення об'єкту до Переліку, після чого ініціатором до Міністерства культури та інфрормаційної політики України (але в положенні досі фрігурує Мінкультури) подається облікова картка та подання на внесення до Реєстру, документи перевіряються (до 10 днів) та розглядаються експертною комісією (до 14 днів), на основі висновку якої Міністерство приймає рішення про занесення об'єкта культурної спадщини до Реєстру за категорією місцевого значення або готує проєкт постанови КМУ про занесення об'єкта культурної спадщини до Реєстру за категорією національного значення або ж відмовляє у занесенні об'єкта до Реєстру в зв'язку із невідповідністю (до 10 днів) [4]. Як бачимо, процедура внесення об'єктів культурної спадщини до Реєстру може тривати більше 3 років, що є досить великим строком, особливо якщо взяти до уваги занедбаний стан великої частини культурної спадщини.

Слід зазначити, що окрім Державного реєстру нерухомих пам'яток, в Україні існує Державний реєстр на- ціонального культурного надбання (ДРНКН), в який, згідно із Положенням про ДРНКН, затвердженим постановою КМУ № 466 від 12 серпня 1992 р., включаються пам'ятки історії, археології, містобудування та архітектури, мистецтва, а також документальні пам'ятки. Проте за даними [11], для ДРНКН створено тільки один набір даних - перелік унікальних предметів Музейного фонду України, в якому сьогодні перебуває 105 одиниць музейних експонатів (в основному це різноманітні артефракти скіфської доби та ікони).

На сайті Національної бібліотеки України імені B.І. Вернадського вказано [12], що у 2000 році було передбачено створення Державного реєстру "Книжкові пам'ятки України" як складової частини ДРНКН, а в 2016 р. затверджено "Порядок відбору рукописних книг, рідкісних і цінних видань до ДРНКН". Силами співробітників НБУВ для організації роботи з відбору книжкових пам'яток до ДРНКС створено та продовжує наповнюватися електронна база даних "Книжкові пам'ятки України", але інформації про включення до нього будь-яких інших підреєстрів, окрім музейних експонатів, нам знайти не вдалось. Окрім того, виникає питання доцільності створення і ведення двох окремих реєстрів, зміст яких частково перетинається, тому видається доцільним внести зміни в законодавчу базу та об'єднати ці реєстри в один, використовуючи сучасні методологічні підходи до створення подібних ресурсів та технології.

Сьогодні охорона культурної спадщини України $є$ далекою від досконалості. Причинами цього $є$ корупція, погане регулювання та управління з боку влади, недосконале законодавство в цій сорері та слабкі санкції за його порушення. Зокрема, досить поширені випадки нецільового використання земель історико-культурного призначення, несанкціонованого використання та руйнування пам'яток археології через низьку культуру та безвідповідальне ставлення окремих суб'єктів господарювання та/ або відсутність охоронних дошок на об'єктах культурної спадщини. Також спостерігається недостатня координація діяльності правоохоронних органів та органів охорони культурної спадщини щодо припинення та попередження правопорушень в зонах охорони об'єктів культурної спадщини та в історичних ареалах населених місць [5; 13].

В Україні відсутній єдиний нормативно-правовий акт, який би регулював діяльність у сфрері охорони та функціонування культурних надбань у державі, натомість $€$ досить велика кількість законів, в яких розпорошені дані норми.

Так, є Закон України "Про охорону культурної спадщини", який відноситься тільки до матеріальної спадщини; Закон України "Про культуру", у якому фрагментами містяться положення щодо регулювання нематеріальної культурної спадщини. Крім того, існує окремий Закон України "Про охорону археологічної спадщини". Всі ці закони не включають достатньо ефективних, стимулюючих положень щодо використання потенціалу культурної спадщини $[9 ; 13 ; 14]$.

Деякі способи управління спадщиною, як-от: приватизація чи оренда, регулюються законодавчими актами, але, як правило, не визначають будь-яких особливостей її правового режиму. Істотною проблемою $€$ 
нечіткість та непогодженість норм цих актів із базовими законами про спадщину. Брак актуальної систематизованої правової інформації про спадок (тематичних баз нормативно-правових актів) $€$ також проблемою для культурної спадщини держави.

Наразі необхідне створення цілісної системи державного управління у сфері збереження культурної спадщини. Ефективно реалізовувати повноваження у цій сорері допоможе формування чіткої управлінської вертикалі від центрального органу виконавчої влади до районного рівня - з належним кадровим забезпеченням. Крім того, існуюча система розподілу функцій управління і контролю у сфері збереження культурної спадщини між кількома центральними органами виконавчої влади не може вважатися оптимальною з огляду на непрофрільність, другорядність цих функцій для окремих інститутів влади [13].

Дуже важливим $€$ законодавчо прописаний моніторинг та незалежні оцінки формування та виконання державної політики у сфрері регулювання культурної спадщини, що, нажаль, в Україні зараз не передбачено. Наявна звітність не дає чіткого уявлення про реальний стан справ в державі, і це гальмує прийняття адекватних управлінських рішень.

Так, Мазур Т.В. у своєму дослідженні констатує той фракт, що для положень окремих законів відсутні механізми реалізації, які мали б бути прописані у відповідних підзаконних актах, відсутній належний контроль за виконанням законодавчих норм у сорері охорони та захисту культурної спадщини; спостерігається низький рівень правової культури та компетентності фрахівців у цій сорері; відсутня ефективна організаційно-управлінська організація, а також системність та координація діяльності органів державної влади та місцевого самоврядування [14].

Охорона культурної спадщини Європи займає важливу роль у політиці Європейського Союзу. Спадщина розглядається як спільний ресурс і загальне благо, що сприятиме ширшому визнанню ЄС. Культурна спадщина в країнах Європейського Союзу охороняється законами, що корегуються після ретельного аналізу цієї сфери, а також у відповідності до сучасних потреб.

У роботі над вдосконаленням законодавства $\in C$ свої зусилля об'єднують експерти різних галузей, включаючи юристів, урядовців та істориків. Європейські держави, які $€$ учасниками Європейської культурної конвенції, активно залучають усі рівні влади, регіональні та місцеві органи влади, громадянське суспільство, приватний сектор та тисячі волонтерів до спільних зусиль, задля сприяння спільному розумінню культурного різноманіття, місцевих навичок та традицій.

Державним органам влади, що відповідають за охорону культурної спадщини, необхідно прислуховуватись та реалізовувати рекомендації ЮНЕСКО та інших міжнародних організацій, враховуючи їх досвід щодо політики культурної спадщини.

Організації громадянського суспільства повинні залучати до сорери охорони культурної спадщини такі установи, які були б незалежними від державних джерел фрінансування. На політику в сфрері культури повинн впливати науковці, дослідники, громадські організації. Їх думка повинна мати не лише консультативний, але і вирішальний голос щодо питань збереження культурних надбань. Крім того, ці незалежні вчені, дослідники та громадські організації повинні мати визнання в місцевій громаді, для яких збереження культурної спадщини є пріоритетним завданням [15].

Важливим і надзвичайно складним питанням сьогодення є охорона і захист культурної спадщини, яка знаходиться на територіях, де триває збройний конфрлікт, причому у даному випадку об'єкти культурної спадщини треба захищати від фрізичного знищення, розкрадання, і від можливого привласнення чи вивезення з території нашої країни.

Також важливим фактором $є$ залученість до різних культурних заходів, прийняття норм щодо об'єднань власників об'єктів культурних надбань, координація волонтерських організацій та створення сприятливих умов для інвестування у збереження та охорону об'єктів культурної спадщини.

Аналізуючи світовий досвід збереження пам'яток культури та архітектури, Україна має велику потребу у необхідності створення некомерційної національної довірчої організації. Статус та правові основи роботи такої організації повинні бути закріплені на законодавчому рівні. Зокрема, слід передбачити створення системи мотивації для донорів (які дають пожертви на збереження об'єктів спадщини), заборону на розподіл прибутку, отриманого, через використання культурної спадщини своїми засновниками та членами; дотримання принципу не відчуження (гарантування того, щоб об'єкт спадщини повинен бути наданий для постійного використання в інтересах всієї громадськості) та звільнення від податку на майно (оскільки об'єкт спадщини перебуває у довірчому управлінні та використовується у інтересах суспільства з гарантією доступу до нього) [16].

Конкретизуючи окремі положення, викладені вище, зазначимо, що актуальною потребою в сфері культурної спадщини України $є$ недостатній розвиток партнерства між державним та приватним сектором. Хоча нині основним джерелом підтримки культури залишається фрінансування з державного і місцевого бюджетів, очевидною $€$ його недостатність для повноцінного функціонування галузі культури, звідки випливає необхідність пошуку альтернативних джерел фрінансування та фрормування інноваційного економічного механізму державного регулювання охороною культурної спадщини. Досвід різних країн свідчить, що об'єкти культурної спадщини - це важливий актив сучасних міст, який може приносити прибуток і істотно впливати на їх економічний розвиток $[17 ; 18]$.

У разі збільшення інвестиційної привабливості сорери культури, ефективним допоміжним інструментом у реалізації культурної політики може стати державноприватне партнерство, під яким слід розуміти укладання договорів про співпрацю органів державного влади та місцевого самоврядування з приватними інвесторами та реалізацію спільних проєктів у сорері надання культурних послуг. Слід зазначити, що особливістю державно-приватного партнерства у сорері культури $\epsilon$ те, що велика увага в таких проєктах приділяється не стільки отриманню прибутку, скільки їх соціальній та культурній значущості, що ускладнює залучення інвестицій у цю 
сфреру. Виходячи зі сказаного вище, першочерговими завданнями у цьому напрямі $є$ ідентифікація проблем, які перешкоджають створенню оптимального механізму державно-приватного партнерства та формування відповідної нормативно-правової бази, зокрема прийняття закону про меценатство, яким би були передбачені інструменти стимулювання приватних інвесторів, які вкладають кошти у розвиток та збереження культурної спадщини [18].

Україна рясніє предметами природи, історії та культури, які можуть залучити туристів з усього світу, тому великий потенціал має розвиток можливості для подорожей Україною, що передбачає, зокрема, розробку туристичних маршрутів, створення та відновлення туристичної інфрраструктури, сприяння держави підготовці кадрів, спроможних організувати якісне туристичне обслуговування як для вітчизняних туристів, так і для іноземців. 3 цією метою треба визначити роль України у глобальному туризмі, створити бренди туристичних принад, розпочати внутрішні та зовнішні рекламні кампанії щодо них.

Ще одне важливе значення для просування України має її участь у нових європейських культурних маршрутах. Співпраця різних громад на основі історії, культурної спадщини та туристичних місць, сприятиме подальшій діловій співпраці і інвестиціям у громади. Це підвищить внесок культурних і творчих продуктів, спорту, туризму.

Одним із важливих аспектів національного збереження культурної спадщини єї̈ популяризація, що матиме значний соціально-економічний ефект і формуватиме позитивний імідж України у всьому світі. Популяризація культурної спадщини передбачає низку заходів, зокрема інформаційно-просвітницькі, які сприятимуть збільшенню рівня інфрормованості українців та світової спільноти стосовно визначних історико-культурних та природних локацій України; розвиток вітчизняних туристичних маршрутів в сегменті етно- та екотуризму, а також рекреаційного відпочинку.

Великий потенціал для охорони та розвитку культурної спадщини мають сучасні інформаційні технології, зокрема заслуговує уваги використання відеолекцій, онлайн-та відеоекскурсій, створення онлайн-каталогів, веб-порталів, інтерактивних карт об'єктів культурної спадщини із використанням геоінформаційних технологій та відкритих даних тощо. Відзначимо, що Міністерство культури та інформаційної політики вже анонсувало реалізацію проєкта у сфрері цифровізації охорони культурної спадщини (е-Спадщина), який передбачає 4 підпроєкта [19]:

1. Цифровізація інфрраструктури музеїв задля осучаснення та прозорості процесів;

2. Електронний реєстр національних об'єктів нематеріальної спадщини, який міститиме їх облікові картки;

3. Реєстр культурної спадщини, який надаватиме інформацію про національні об'єкти матеріальної культурної спадщини та передбачає створення персональних кабінетів стейкголдерів, зокрема органів охорони КС, органів державної влади, отримувачів адміністративних послуг, громадян тощо), інтеграцію з будівельними та просторовими геоінформаційними системами для проєктно-планувальної та містобудівної документації;

4. Музейний фоонд України: ресурс, що акумулюватиме інфрормацію про цінності, що зберігаються в музеях та бібліотеках та інтегруватиметься з прикордонними службами для перешкоджання незаконному перетину кордону культурними цінностями та забезпечуватиме можливість оформлення онлайн-дозволів на їх вивезення.

Реалізація перших двох проєктів запланована вже на кінець цього року, третього та четвертого - на грудень 2023 року [19].

Під час опрацювання регіональних стратегій розвитку слід більше уваги звернути на важливий економікогеографрічний чинник і потребу врахування всього різноманіття існуючих у регіонах історико-культурних пам'яток.

Таким чином, можна виділити ряд фракторів, які сприятимуть покращенню державного регулювання у сорері охорони культурних надбань $[2 ; 6 ; 9 ; 17]$ :

- створення цілісної системи державного управління у сорері збереження культурної спадщини із чіткою управлінською вертикаллю, уникнення розпорошення функцій управління та контролю між кількома ЦОВВ;

- проведення державними органами та органами місцевого самоврядування регулярних консультацій 3 громадянами та профільними організаціями щодо проблем, потреб та побажань у сорері охорони культурного спадку держави;

- налагодження механізмів громадського контролю за використанням бюджетних коштів, виконанням цільових програм;

- сприяння приватним ініціативам у галузі збереження та розвитку культурної спадщини, створення умов для підвищення інвестиційної (меценатської) активності, поліпшення туристичної привабливості міста;

- укладання охоронних договорів на пам'ятки та об'єкти культурної спадщини міста з користувачами (власниками) і балансоутримувачами;

- забезпечення повноти й доступності інформації про пам'ятки та об'єкти культурної спадщини міста, запуск повноцінного електронного реєстру культурної спадщини;

- забезпечення безперервного моніторингу стану збереження пам'яток та об'єктів культурної спадщини;

- розробка системи заходів з інфрормування населення щодо важливості збереження об'єктів культурної спадщини загалом, і донесення конкретної інфрормації до користувачів (власників) і балансоутримувачів пам'яток та об'єктів культурної спадщини.

\section{ВИСНОВОК}

Перед Україною стоїть важливе завдання - удосконалити роботу з охорони культурного спадку. Необхідно впорядкувати національне законодавство, яке повинне відповідати міжнародним зобов'язанням України, забезпечити ефективне застосування закону, а також сприяти виробленню стратегії гуманітарного розвитку сучасної України, яке потребує перегляду державного регулювання у сфері захисту культурних надбань.

Основними напрямами роботи із спадщиною в Україні можна визначити її охорону та збереження, чому 
значною мірою сприятиме повноцінне фрункціонування електронного Державного реєстру нерухомих пам'яток України, популяризацію та розвиток туризму.

Враховуючи рекомендації міжнародних організацій та кращі зарубіжні практики, Україні необхідно встановити законодавчі рамки використання об'єктів культурної спадщини (охорони, збереження, реставрації, археологічних розкопок, документування тощо), створити умови для ведення господарської діяльності і забезпечення координації інтересів різних суспільно-політичних груп щодо спадщини, врегулювання конфліктів щодо культурної спадщини на міжнародній арені.

Діяльність у галузі охорони культурного спадку має грунтуватися на якісній комунікації представників різних професій. Позитивні зміни у сфері охорони культурної спадщини можна очікувати лише тоді, коли всі, хто бере участь у цьому процесі, будуть залучені до співпраці. Тому співробітництво між експертами різних сорер, державною та місцевою владою має бути пріоритетом державного регулювання у сфері культурної спадщини.

Під час вирішення проблем щодо недостатнього орінансування об'єктів культурної спадщини потрібно залучати механізми державно-приватного партнерства, для стимуляції якого доцільно розробити комплекс нормативно-законодавчих актів щодо активізації меценатства та інвестиційної діяльності у сфрері культури.

\section{Література:}

1. Поливач К.А. Культурна спадщина та її вплив на розвиток регіонів України. К.: Інститут географрії НАН України, 2012. 208 с.

2. Концепція державної політики реформування сорери охорони нерухомої культурної спадщини. Міністерство культури України. 2018. URL: http:// mincult.kmu.gov.ua/control/publish/article?art_id=245358162 (Дата звернення: 20.05.2021).

3. Державний реєстр нерухомих пам'яток України. Міністерство культури та інформаційної політики України. URL: https://mkip.gov.ua/content/derzhavniyreestr-neruhomih-pamyatok-ukraini.html (Дата звернення: 13.05.2021).

4. Порядок обліку об'єктів культурної спадщини. Затв. наказом Міністерства культури України 11.03.2013. В редакції від 27.06.2019 року. URL: https:/ /zakon.rada.gov.ua/laws/show/z0528-13\#Техt (Дата звернення: 20.05.2021).

5. Комплексна програма збереження та використання пам'яток культурної спадщини Закарпатської області на 2016-2020 роки. URL: https:/ / kultura-zak.gov.ua/ images/pdf/rish_91.pdf (Дата звернення: 20.05.2021).

6. Міська цільова програма з охорони та збереження пам'яток культурної спадщини м. Чернігова на 20192021 роки. URL: https://chernigiv-rada.gov.ua/miskiprogramy/id-35710/(Дата звернення: 20.05.2021).

7. Міська цільова програма "Охорона та збереження культурної спадщини м. Києва на 2019-2021 роки". Київська міська рада. 2018. URL: https://kmr.gov.ua/sites / default/files /463-6514.pdf (Дата звернення: 20.05.2021).

8. Програма збереження культурної спадщини Полтавської області на 2021-2023 роки. URL: https:// oblrada-pl.gov.ua/ses /8/2/52.pdf (Дата звернення: 20.05.2021).
9. Аналіз проблем у законодавчому регулюванні збереження та управління культурною та природною спадщиною в Україні. ГО "Агентство з розвитку приватної ініціативи", 2019. URL: https://taif.org.ua/wpcontent/uploads/2019/02/Heritage_Legislation_Analyses.pdf (Дата звернення: 20.05.2021).

10. Мещеряков В.В. Механізми державного регулювання у сорері охорони історико-культурної спадщини та пам'яток архітектури в регіонах: автореф. дис. ...канд. н.держ.упр.: 25.00.02 / НАДУ. Київ, 2016. 20 с.

11. Державний реєстр національного культурного надбання. Портал відкритих даних. Останнє оновлення набору даних: 06.11.2020 p. URL: https://data.gov.ua/ dataset/014aba3a-63ed-4edf-b6b1-b26f1ad29953/ resource/38045038-2152-4769-8fd4-c0a59f3c333c

12. Матеріали до Державного реєстру національного культурного надбання. Національна бібліотека імені B.I. Вернадського. URL: http://www.nbuv.gov.ua/ node /610 (Дата звернення: 20.05.2021).

13. Литвиненко О.М. Напрями вдосконалення правових та інституційних механізмів збереження культурної спадщини. Національний інститут стратегічних досліджень, 15.04.2020. URL: https://niss.gov.ua/ doslidzhennya/socialna-politika/napryami-vdoskonalennya-pravovikh-ta-instituciynikh-mekhanizmiv (Дата звернення: 20.05.2021).

14. Мазур Т.В. Охорона культурної спадщини в Україні: історико- й теоретико-правове дослідження: дис.... д-ра юр. наук: 12.00.01 / Національна академія внутрішніх справ Міністерства внутрішніх справ України. Київ, 2021. 423 с.

15. Cultural heritage. Copernicus Service in Support to EU External Action. URL: https://sea.security.copernicus.eu /domains / cultural-heritage / (Дата звернення: 20.05.2021).

16. Rybchynskyy O. Insights into the programmes of Ukraine's Cultural Heritage Conservation. CHOICE. Cultural Heritage: Opportunity for Improving Civic Engagement. URL: http://choiceproject.eu/insightsinto-the-programmes-of-ukraines-cultural-heritageconservation/\#10 (Дата звернення: 20.05.2021).

17. Мещеряков В. В. Сучасні підходи до вдосконалення механізмів державного регулювання зі збереження та популяризації історико-культурної спадщини та пам'яток архітектури. Державне управління: удосконалення та розвиток. 2015. № 9. URL: http://www.dy.nayka.com.ua/pdf/9_2015/17.pdf (Дата звернення: 20.05.2021).

18. Валевський О.Л. Актуальність розвитку державно-приватного партнерства у сорері культурної політики. Національний інститут стратегічних досліджень. 28.10.2020. https://niss.gov.ua/doslidzhennya/ gumanitarniy-rozvitok/aktualnist-rozvitku-derzhavnoprivatnogo-partnerstva-u-sferi (Дата звернення: 20.05.2021).

19. Проєкти цифрової трансформації. Дія. Цифрова держава. URL: https://plan2.diia.gov.ua/projects (Дата звернення: 20.05.2021).

\section{References:}

1. Polyvach, K.A. (2012), Kulturna spadshchyna ta yii vplyv na rozvytok rehioniv Ukrainy [Cultural heritage and 
its impact on the development of the regions of Ukraine]. Instytut heohrafii NAN Ukrainy, Kyiv, Ukraine.

2. The official site of Ministry of Culture of Ukraine (2018), "The concept of state policy of reforming of the sphere of protection of immovable cultural heritage", available at: http://mincult.kmu.gov.ua/control/ publish/article?art_id=245358162 (Accessed 20 May 2021).

3. The official site of Ministry of Culture and Information Policy of Ukraine (2019), "State Register of Immovable Monuments of Ukraine", available at: https:/ /mkip.gov.ua/content/derzhavniy-reestr-neruhomihpamyatok-ukraini.html (Accessed: 13 May 2021).

4. The official site of Verkhovna Rada of Ukraine (2013), "Procedure for registration of cultural heritage sites", available at: https://zakon.rada.gov.ua/laws / show / z0528-13\#Text (Accessed: 20 May 2021).

5. The official site of Transcarpathian Regional Council (2015), "Comprehensive program for the preservation and use of cultural heritage of the Transcarpathian region for 2016-2020", available at: https://kultura-zak.gov.ua/ images/pdf/rish_91.pdft (Accessed: 20 May 2021).

6. The official site of Chernihiv City Council (2018), "City target program for the protection and preservation of cultural heritage of Chernihiv for 2019-2021", available at: https://chernigiv-rada.gov.ua/miski-programy/id35710/(Accessed: 20 May 2021).

7. The official site of Kyiv City Council (2018), "City target program "Protection and preservation of cultural heritage of Kyiv for 2019-2021", available at: https:/ / kmr.gov.ua/sites/default/files/463-6514.pdf (Accessed: 20 May 2021).

8. The official site of Poltava Regional Council (2020), "Program for the preservation of cultural heritage of Poltava region for 2021 - 2023", available at: https:// kultura-zak.gov.ua/images/pdf/rish_91.pdft (Accessed: 20 May 2021).

9. The site of NCO "Agency for the Development of Private Initiative" (2019), "Analysis of problems in the legislative regulation of conservation and management of cultural and natural heritage in Ukraine", available at: https://taif.org.ua/vp-tsontent/uploads/2019/02/ Heritage_Legislation_Analyses.pdf (Accessed: 20 May 2021).

10. Meshcheryakov, V.V. (2016), "Mechanisms of the state regulation in the sphere of protection of historical and cultural heritage and monuments of architecture in the regions", Abstract of Ph.D. dissertation, Public Administration, NADY, Kyiv, Ukraine.

11. Open data portal (2019), "State Register of National Cultural Heritage", available at: https://data.gov.ua / dataset/014aba3a-63ed-4edf-b6b1-b26f1ad29953/ resource / 38045038-2152-4769-8fd4-c0a59f3c333c (Accessed: 20 May 2021).

12. The site of the V.I. Vernadsky National Library (2021), "Materials to the State Register of National Cultural Heritage", available at: http:/ / www.nbuv.gov.ua/node / 610 (Accessed: 20 May 2021).

13. Litvinenko, O.M. (2020), "Directions for improving legal and institutional mechanisms for preserving cultural heritage", The National Institute for Strategic Studies, available at: https://niss.gov.ua/doslidzhennya/ socialna-politika/napryami-vdoskonalennya-pravovikh-tainstituciynikh-mekhanizmiv (Accessed: 20 May 2021).

14. Mazur, T. V. (2021), "Protection of cultural heritage in Ukraine: historical and theoretical legal research", Abstract of doctor of Science dissertation, Law, National Academy of Internal Affairs of Ukraine, Kyiv, Ukraine.

15. The site of Copernicus Service in Support to EU External Action (2021), "Cultural heritage", available at: https://sea.security.copernicus.eu/domains/culturalheritage / (Accessed: 20 May 2021).

16. Rybchynskyy, O. (2017), "Insights into the programmes of Ukraine's Cultural Heritage Conservation", CHOICE. Cultural Heritage: Opportunity for Improving Civic Engagement, available at: http:/ / choiceproject.eu / insights-into-the-programmes-of-ukraines-culturalheritage-conservation/\#10 (Accessed: 20 May 2021).

17. Mescheryakov, V. (2015), "Modern approaches of improving mechanisms of state regulation with conservation and promotion the historical and cultural heritage and monuments", Derzhavne upravlinnya: udoskonalennya ta rozvytok, vol. 9, available at: http:// www.dy.nayka.com.ua/pdf/9_2015/17.pdf (Accessed: 20 May 2021).

18. Valevsky, O.L. (2020), "The relevance of the development of public-private partnership in the field of cultural policy", The National Institute for Strategic Studies, available at: https://niss.gov.ua/doslidzhennya/gumanitarniy-rozvitok/aktualnist-rozvitku-derzhavno-privatnogo-partnerstva-u-sferi (Accessed: 20 May 2021).

19. The site of Diia (2021), "Digital state. Digital transformation projects", available at: https://plan2.diia.gov.ua/projects (Accessed 29 May 2021).

Стаття надійшла до редакцї̈ 23.06.2021 p.

\section{www. economy.nayka.com.ua} Електронне фахове видання

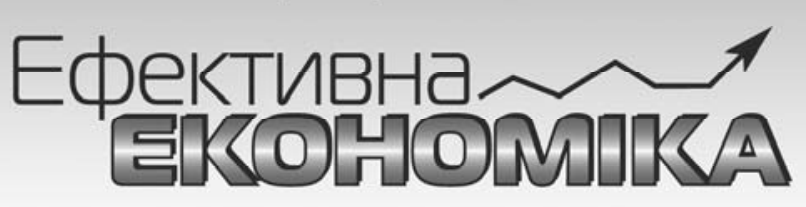

\section{Виходить 12 разів на рік}

Журнал включено до переліку наукових фахових видань України з ЕКОНОМІЧНИХ НАУК (Категорія «Б»)

Спеціальності - 051, 071, 072, 073, 075, 076, 292

$$
\begin{array}{r}
\text { e-mail: economy_2008@ukr.net } \\
\text { тел.: (044) 223-26-28 } \\
\text { (044) 458-10-73 }
\end{array}
$$

